\title{
HAK MANTAN NARAPIDANA KORUPSI SEBAGAI CALON ANGGOTA DEWAN PERWAKILAN RAKYAT DAN DEWAN PERWAKILAN RAKYAT DAERAH DALAM PEMILIHAN UMUM
}

\author{
Gede Nofantara Putra, I Gusti Bagus Suryawan, Ida Ayu Putu Widiati \\ Fakultas Hukum Universitas Warmadewa, Denpasar-Bali, Indonesia \\ nofantaraputra96@gmail.com, suryawanmeraku@gmail.com,widiati_dayu@yahoo.co.id
}

\begin{abstract}
Abstrak
Indonesia merupakan Negara demokrasi konstitusional, Negara demokrasi pemilihan umum termasuk pemilihan kepala daerah (pemilukada) adalah suatu cara sebagai wujud kedaulatan rakyat dalam berperan aktif pada penyelenggaraan Negara. Eksistensi pemilukada diadakan disemua jenis tataran politik baik secara sistem demokrasi, otoriter ataupun totaliter dan diakui oleh Negara penganut asas kedaulatan rakyat. Penelitian ini mengkaji pengaturan persyaratan pencalonan anggota dewan perwakilan rakyat dan dewan perwakilan rakyat daerah pada pemilu (pemilihan umum) dan menjelaskan implikasi dari narapidana korupsi yang mencalonkan diri sebagaia anggota dewan perwakilan rakyat dan dewan perwakilan rakyat daerah. Penelitian ini menggunakan metode penelitian hukum normatif, pendekatan secara Undang-undang dan pendekatan konseptual, sumber bahan hukum primer dan bahan hukum sekunder, studi dokumen dan studi kepustakaan, serta analisis interpretasi hukum dan analisis deskriptif. Hasil penelotia menunjukkan bahwa pencalonan anggota dewan perwakilan rakyat dan dewan perwakilan rakyat daerah dimulai dari proses di partai politik. Partai politik mempunyai kriteria untuk calon anggota, kemudian apabila kriteria tersebut terpenuhi oleh calon maka calon tersebut resmi menjadi kadernya, atau bagian dari anggota partai politik.
\end{abstract}

Kata Kunci: Hak, Mantan Narapidana Korupsi, Pemilihan Umum

\begin{abstract}
Indonesia is a constitutional democracy which in a democratic country, general elections including regional head elections (Pemilukada) are a way of being a form of people's sovereignty in playing an active role in state administration. The existence of post-conflict local elections is held at all types of political levels either in a democratic, authoritarian or totalitarian system and is recognized by States adhering to the principle of people's sovereignty. As for the formulation of the problem of this scientific paper, namely (1) How are the requirements for the nomination of members of the People's Representative Council and Regional People's Representative Council members in the election (general election)? (2) What are the implications of corruption convicts running for members of the people's representative council and regional people's representative council? This research uses normative legal research methods, statutory and conceptual approaches, primary and secondary legal sources, document studies and literature studies, and analysis of legal interpretations and descriptive analysis. On human rights, a person who has served a sentence as a prisoner has the same rights as other citizens and because the prisoner has already served the consequences of his actions with a sentence.
\end{abstract}

Keywords: Rights, Former Corruption Prisoners, General Elections

\section{PENDAHULUAN}

Negara hukum atau sering disebut Rechtsstaat merupakan pedoman yang berparadigma bahwa suatu Negara serta alat kekuasaan yaitu pemerintahan tidak dibenarkan berjalan dari kekuasaanbelaka sebaliknya harus berpedoman atas dasar suatu kebenaran hukum di Indonesia (hukum positif) ialah ketetapan dimana saat bagian muncul kokoh ditempat keabsahan kaidah ketetapan dimana dijadikan aturan ialah Undang-undang Dasar Negara Republik Indonesia (Winarno, 2013). Negara Indonesia merupakan kawasan kaidah atau sering disebut dengan Rechsstaat bukan negara kekuasaanMachsstaast. Ciri dari negara hukum diantaranya yaitu adanya pembagian atau pemisahan kekuasaan dalam menjamin hak-hak asasi manusia, adanya suatu peradilan administrasi, pemerintahan berdasarkan suatu peraturan (Wetmatigheid Van Bestuur) dan perindungan yang ada terhadap hak asasi manusia (M.D, 2000).

Selain merupakan sebagai Negara hukum, Indonesia adalah Negara yang demokrasinya konstitusional. Pada negara yang demokrasi pemilihan umum termasuk pemilihan suatu kepala daerah 
adalah cara dalam mewujudkan kedaulatan warga negara untuk ikut berperan aktif pada proses penyelenggaraan dalam suatu negara (Respationo, 2013). Negara penganut asas kedaulatan rakyat mengakui eksistensi pemilihan umum dan dilaksanakan disemua macam tataran politik baik sistem demokrasinya, otoriternya ataupun totaliternya (Zazili, 2012). Pada suatu kawasan kerakyatan pemilihan umum diibaratkan bagaikan tolak ukur dan lambing semenjak metode kerakyatan Negara tersebut. Pemilihan umum yang dilaksanakan di Negara Indonesia adalah bagian dalam pembentukan pemerintahan yang demokratis dengan cara suatu sistem yang adil dan jujur. Dalam Pasal 28 huruf D Undang-undang Dasar Negara Republik Indonesia 1945 menyatakan yaitu, setiap orang berhak memperoleh kesempatan yang sama dalam pemerintahan.

Pada bunyi dari pasal tersebut, pemilu merupakan hak suatu politik dari warga Negara dalam pemilu (pemilihan umum) termasuk pemilukada (pemilihan kepala daerah) yaitu hak untuk dipilih dan memilih suatu hak asas manusia yang dijamin dalam Ketatapan Undang-undang Negara Kesatuan Republik Indonesia tahun 1945. Pasal 1 ayat (2) Undang-undang Dasar Negara Republik Indonesia Tahun 1945 yang menyebutkan "bahwa kedaulatan berada di tangan rakyat dan dilaksanakan menurut ketentuan undang-undang dasar". Pasal 1 ayat 3 undang-undang dasar Negara Republik Indonesia tahun 1945 menyatakan "bahwa negara Indonesia merupakan Negara hukum (Asshiddiqie, 1994). Pada ihwal berikut sudah terang bahwasannya daerah Indonesia patut melindungi terselenggaranya suatu pemilihan umum dimana bersifat leluasa dengan tidak terdapatnya di satu sisi menjadi maksud bahwasannya daerah Indonesia ialah daerah kaidah (Rahayu, 2015). Hak Asasi Manusia (HAM) adalah hak hukum yang berusaha menerjemahkan keyakinan mengenai martabat manusia ke dalam bahasa hukum yang konkrit dengan tujuan agak hak itu seperlunya dapat dipaksakan pelaksanaanya di muka pengadilan (Magnis-Suseno, 2001). Konsep dari hak asasi manusia pada perkembangannya sangat keterkaitan dengan konsepsi Negara hukum.

Pemilihan umum bukan sekadar berhubungan hanya atas kepentingan negara atas legalitas dominasi melainkan pula bagaikan cara penduduk memahami relevansi serta harapan ditengah semangat bernegara dan juga berbangsa (Affan, 2015). Status mantan narapidana sebagai calon yang berpartisipasi dalam pemilihan umum dan pemilihan kepala daerah sangat sensitive dibicarakan.Niat dari suatu lembaga penyeleggaraan pemilihan umum dalam mencari calon terbaik pada pemilu dan pemilukada wajib dibantu.Keinginan bagus berikut wajib pula mencermati berasal darimana aturan tersebut selaras dengan tujuan aturan yang sepatutnya, bergunan serta berkepastian norma. Setelah ditetapkannya Peraturan Komisi Pemilihan Umum Nomor 20 Tahun 2018 tentang Pencalonan Anggota Dewan Perwakilan Rakyat Daerah Kabupaten atau Kota, Anggota Dewan Perwakilan Rakyat dan Anggota Dewan Perwakilan Rakyat Daerah Provinsi oleh sebab itu peraturan mengenai pembatasan eks tahanan kasus korupsi menjadi peserta dewan telah mampu dibuatkan. Kejadian ini menjadi perdebatan diberbagai kalangan dalam penolakan tersebut terjadi karena KPU (Komisi Pemilihan Umum) dianggap melanggar Undang-undang.Pada undang-undang tersebut mantan narapidana yang telah melakukan masa hukumannya 5 tahun atau lebih bisa mencalonkan diri menjadi anggota legislative selama yang bersangkutan mengumumkan dirinya kepada public mengenai hukuman yang pernah menjeratnya.

Selainnya juga larangan oleh Komisi Pemilihan Umum diatas dianggap berlawanan dengan pasal 28 huruf D Undang-undang Dasar Negara Republik Indonesia tahun 1945. Warga Negara yang mantan tahanan terutama kasus korup dianggap mempunyai hak politik yang sama dengan warga Negara yang lainnya yaitu suatu hak yang dijamin oleh konsitusi. KPU telah mengeluarkan Peraturan Komisi Pemilihan Umum Nomor 20 Tahun 2018 tentang Pencalonan Anggota DPRD Kabupaten/Kota, Angggota DPR dan Anggota DPRD Provinsi pada pemilihan umum 2019. PKPU ini mejadi pedoman Komisi Pemilihan Umum dalam melaksanakan tahapan pencalonan Anggota Legislatif dari 2019 hingga kedepannya nanti. Norma tersebut diperoleh dalam ketentuan pasal 7 ayat 1 huruf $\mathrm{H}$ disebutkan bahwasannya bukan mantan terpidana bandar narkoba, kejahatan seksual terhadap anak atau korupsi. Komisi Pemilihan Umum sebagai lembaga yang menyelenggarakan pemilihan umum pada april 2018 menyampaikan keinginannya untuk melarang eks tahanan kasus korupsi sebagai peserta legislative sebagai DPD maupun DPR, Sehingga kontra maupun pro mengenai masalah ini timbul dalam lingkungan pemerhati pemilihan umum, akademisi, lapisan masyarakat dan partai politik. Berdasarkan latar belakang yang telah diuraikan maka oenelitian ini bertujuan untuk Mengkaji pengaturan persyaratan pencalonan anggota dewan perwakilan rakyat dan 
anggota dewan perwakilan rakyat daerah dalam pemilihan umum dan menjelaskan implikasi dari narapidana korupsi yang mencalonkan diri sebagai anggota dewan perwakilan rakyat dan dewan perwakilan rakyat daerah

\section{METODE PENELITIAN}

Metode penelitian yang dipergunakan dalam penelitian ini yaitu penelitian hukum normatif yang merupakan studi kepustakaan. Pengkajian hukum normatif atau kepustakaan tersebut mencakup penelitian terhadap norma-norma hukum.Tipe pendekatan masalah yang digunakan yaitu pendekatan secara Perundang-undangan (Statute Approach) dan Pendekatan konseptual (Conceptual Approach). Sumer data yang digunakan adalah data primer dan sekunder. Bahan hukum primer didapat melalui studi lapangan dengan menggunakan tahapan observasi dan wawancara kepada informan atau narasumber yang memiliki kecakapan mengenai teman penulisan ini. Bahan sekunder didapat melalui Undang-undang dan beberapa bahan tulisan hukum yang memiliki tema yang sama dengan penulisan ini. Bahan-bahan hukum yang didapat kemudian dianalisis menggunakan teknik deskriptif kualitatif, yang dimana teknik ini memberikan gambaran mengenai tema tulisan ini dengan kata-kata atau kalimat yang dipisah menurut ketegori untuk memperoleh kesimpulan.

\section{HASIL DAN PEMBAHASAN}

\section{Pengaturan Persyaratan Pencalonan Anggota Dewan Perwakilan Rakyat dan Dewan Perwakilan Rakyat Daerah dalam Pemilihan Umum}

Pemilihan umum merupakan salah satu bagian utama dari suatu demokrasi. Demokrasi tidak langsung ataupun demokrasi modern di Negara Indonesia mengandung pengertian bahwa yang melaksanakan kedaulatan yaitu wakil rakyat dengan ditentukan sendiri oleh rakyatanya. Dalam menentukan siapa yang mempunyai wewenang mewakili rakyat maka dilakukanlah yang namanya pemilihan umum. Pemilu merupakan bagian dari proses demokrasi dlam menentuka wakil rakyat yang akan mewakili masyrakat yang akan duduk di suatu lembaga perwakilan dari rakyat dan bagian dari pelayanan hak asasi suatu warga negara pada bidang politik (Syarbaini, 2002). Pemilu diinginkan para wakil rakyat yang dipilih benar-benar mewakili keinginan dari rakyat, aspirasi dan keragaman yang memilihnya.

Pada proses pencalonan angota dewan perwakilan rakyat dan dewan perwakilan rakyat daerah bermula dari suatu partai politik. Partai politiklah yang memiliki kriteria bagi calon anggota akan diajukan selanjutnya apabila kriteria dapat dipenuhi bagi peserta anggota oleh sebab itu peserta anggota itu sah dan bisa dijadikan kandidat ataupun komponen oleh suatu peserta dari ParPol. Tahap lanjutnya dengan kandidat menjadi calon anggota legislatif ataupun bakal dari calon anggota dewan perwakilan rakyat, dalam undang-undang republik Indnesia nomor 7 Tahun 2017 tentang Pemilihan Umum pada pasal 20 ayat 1 harus memenuhi persyaratan sebagai berikut :

1. Telah berumur 21 tahun atau lebih.

2. Bertakwa kepada Tuhan Yang Maha Esa.

3. Bertempat tinggal di wilayah Negara Kesatuan Republik Indonesia.

4. Dapat membaca, berbicara dan/atau menulis dalam Bahasa Indonesia.

5. Berpendidikan sangat kecil ialah tamat SMA, Madrasah Aliyah, SMK, Madrasah Aliyah Kejuruan atau perguruan yang lainnya yang segolongan.

6. Setia kepada pancasila, negara kesatuan republik Indonesia, bhinneka tunggal ika, dan undangundang dasar negara republik Indonesia.

7. belom sempat ditahan berlandaskan vonis majelis hukum dimana sudah meperoleh kekuatan hukum yang tetap karena melakukan tindak pidana yang diancam dengan pidana penjara 5 (lima) tahun atau lebih, kecuali secara terbuka dan jujur mengemukakan kepada public bahwa yang bersangkutan mantan narapidana.

8. stabil fisik, jiwa serta leluasa pada penyelewengan narkotika.

9. tercatat menjadi pemilih.

10. Sanggup berkarya dengan banyak durasi.

11. menangguhkan diri dari bagian peserta kepala daerah, wakil kepala daerah, ASN, anggota TNI, anggota Kepolisian Negara Republik Indonesia, direksi, komisaris, dewan pengawas serta pegawai dalam BUMN dan/atau BUMD, atau badan usaha lainnya dimana pendanaannya berasal 
pada finansial negara, dimana dijelaskan dalam nota penangguhan diri dimana belum bisa dicabut lagi.

12. Sanggup akan tidak berkerja dalam hal akuntan publik, advokat, notaris, PPAT, atau menangguhkan kegiatan fasilitator muatan dan pelayanan dimana berkaitan dalam pendanaan negara dan bahkan kegiatan berbeda dimana bisa membangkitkan konfrontasi relevansi bersama tanggung jawab, kedaulatan, serta kebebasan selaku peserta dari DPR, DPRD provinsi, dan DPRD kabupaten/kota sejalan terhadap ketetapan perundang-undangan yang berlaku.

13. Sanggup akan tidak mempunyai pangkat lebih dari satu menjadi pemangku negara seperti direksi, komisaris, dewan pengawas dan karyawan dalam BUMN dan/atau BUMD bahkan badan usaha lainnya dimana pendanaanya berasal pada finansial negara.

14. Menjabat peserta Parpol anggota Pemilu.

15. dikaderkan pada satu institusi perwakilan, dan

16. dikaderkan pada satu daerah pemilihan.

\section{Implikasi Narapidana Korupsi Mencalonkan Diri Sebagai Calon Anggota Legislatif}

Penentuan bakal calon legislatif baik DPR maupun DPRD berawal pada proses internal partai politik peserta pemilihan umum. Pada partai politiklah yang diusulkan yang akan menjadi calon dalam setiap wilayah pemilihan walaupun Undang-undang mengatur persyaratan formal yang mesti dipenuhi seseorang yang menjadi benih peserta. Akan sulitnya merubah lembaga legislatif jika seorang yang dicalonkan oleh partai politik mempunyai track record yang banyak masalah.

Data melihatkan tidak sedikit mantan narapidana khususnya korupsi banyak mengajukan diri dan maju pada pemilu legislatif di tahun 2019. Majunya mantan narapidana korupsi sebagai peserta anggota dewan belum terlepas pada Putusan Mahkamah Agung dimana telah memvonis uji materi yang terdapat pada ketentuan pasal 4 ayat (3) PKPU nomor 20 Tahun 2018 mengenai pencalonan DPR dan DPRD kabupaten/kota atas ketetapan Undang-undang nomor 7 Tahun 2017 mengenai Pemilihan Umum. akan calon legislative narapidana korupsi menjadi MS (Memenuhi Syarat). Ini artinya, mantan narapidana korupsi diberikan untuk maju menjadi calon legislative. Dari putusan Mahkamah Agung tersebut dimungkinkan banyaknya calon legislatif mantan narapidana korupsi yang awalnya tidak lolos oleh KPU karena adanya peraturan komisi pemilihan umum Nomor 20 Tahun 2018 pasal 4 ayat (3) akan dapat lolos menjadi bakal calon legislatif.

Mantan napi korupsi memiliki hak yang sama dengan warga masyarakat yang lainnya dengan syarat-syarat hukum positif di Negara Indonesia satupun belum terdapat yang menyimpang dalam hal belum didapatkannya eks terpidana korupsi sebagai peserta dewan. Dalam undang-undang no. 39 tahun 1999 bab I ketentuan umum dalam pasal 1 ayat (1) menyebutkan makna hak asasi manusia merupakan seperangkat hak yang melekat pada keberadaan dan hakikat manusia sebagai mahkluk Tuhan Yang Maha Esa serta merupakan anugerah-Nya yang wajib dilindungi, dihormati dan dijunjung tinggi oleh Negara hukum serta setiap orangnya demi kehormatan serta perlindungan martabat dan harkat kemanusiaan itu.

Tiap individu pada aturannya ialah sudah melakoni penahanan dikarenakan oleh perilakunya wajib dibalikkan semua kemerdekaan yang dipunyainya. Sebab mantan seorang narapidana juga mempunyai perlakuan dan hak yang sama oleh negara serta tidak terbatas pada apapun seperti pada Yurisprudensi Putusan Mahkamah Agung no. 46 P/HUM/2018 menyatakan bahwa mantan narapidana dapat mencalonkan diri sebagai anggota legislatif. Setiap perorangan dibantu sebab semesta kebebasan dimana menempel pada keleluasaan, kepemilikan bahkan hidup. Hal ini ialah merupakan kepunyaan tiap perorangan serta belum bisa dilepaskan pada negara. Bantuan pengawasan daripada kewenangan dimana belum bisa dilepaskan tersebut diberikan terhadap negara lewat perjanjian kemasyarakatan. beliau memaparkan mengenai terdapatnya pemerintahannya dan hukumnya yang diciptakan pada warga negara terbit dikarenakan pemahaman berdasarkan kewenangan dimana terdapat oleh nasibnya selaku khalayak (Lock, 2006).

Dari adanya ketetapan MA nomor $46 \mathrm{P} / \mathrm{HUM} / 2018$ tentang adanya pemulihan kembali kebebasan dan hak seseorang yang sudah menjalani masa hukuman tidak membatasi hak konstitusional dijadikan maksud oleh struktur sosialisasi beralaskan atas Ketetapan Peraturan Perundang-undangan nomor 12 tahun 1995 menganai Pemasyarakatan. Pengembalian ulang kebebasan dan haknya berikut dimaksudkan supaya individu dimana telah melaksanakan proses 
penahanan turut berlaku pada pembentukan serta bisa tumbuh dengan lumrah menjadi masyarakat yang bagus serta bertanggungjawab.

\section{SIMPULAN DAN SARAN}

\section{Simpulan}

Berdasarkan uraian-uraian dan pembahasan diatas dapat diambil beberapa kesimpulan bahwa proses pencalonan anggota dewan perwakilan rakyat dan dewan perwakilan rakyat daerah dimulai dari proses di partai politik. Partai politik mempunyai kriteria untuk calon anggota, kemudian apabila kriteria tersebut terpenuhi oleh calon maka calon tersebut resmi menjadi kadernya, atau bagian dari anggota partai politik. Kemudian untuk mencalonkan diri sebagai calon legislatif atau bakal calon anggota dewan perwakilan rakyat pada undang-undang nomor 8 tahun 2012, bab VII, bagian kesatu tentang persyaratan bakal calon anggota dewan perwakilan rakyat, dewan perwakilan rakyat daerah provinsi dan dewan perwakilan rakyat daerah kabupaten/kota pada pasal 51 menulis syarat bakal calon DPR dan DPRD yaitu WNI. Berdasarkan HAM eks terpidana menyandang kewenangan sama menjadi WNI serta belum dapat disekat dengan apa saja dikarenakan telah melaksanakan putusan dalam bagian kewajiban terhadap kelakuannya. Narapidana juga sama mempunyai hak untuk menjadi calon legeslatif setelah adanya putusan dari Mahkamah Agung.

\section{Saran}

Adapun saran yang bisa diberikan pada penelitian ini yaitu diharapkan kepada pemerintah agar diatur pencalonan sebaik mungkin dan seketat mungkin sehingga terseleksi betul calon yang ingin menjadi anggota legislatif. Partai politik juga mempunyai peran penting dalam menentukan calon yang ingin diusung agar benar-benar calon tersebut mempunyai kapasitas dan integritas di bidangnya. Kepada semua kalangan masyarakat diharapkan dapat menerima mantan narapidana yang telah selesai menjalani hukumannya dan kembali kemasyarakat, karena seorang mantan narapidana juga memiliki hak yang sama dengan dengan warga lainnya. Narapidana juga memiliki kesempatan untuk memperbaiki diri dan menjadi calon legislatif.

\section{DAFTAR PUSTAKA}

Affan, S. (2015). Demokrasi, Partai Politik dan Pemilihan Kepala Daerah. Cosmogov, 1(1), 12-24.

Asshiddiqie, J. (1994). Gagasan Kedaulatan Rakyat Dalam Konstitusi dan Pelaksanaannya di Indonesia. Jakarta. PT Ichtiar Baru Van Hoeve.

Lock, J. (2006). Kuasa Itu Milik Rakyat, Esai Mengenai Asal Mula Sesungguhnya, Ruang Lingkup, dan Maksud Tujuan Pemerintahan Sipil. Yogyakarta. Kanisius.

M.D, M. M. (2000). Demokrasi dan Konstitusi di Indonesia. Jakarta. Rineka Cipta.

Magnis-Suseno, F. (2001). Etika Politik. Jakarta. Gramedia Pustaka Utama.

Rahayu. (2015). Hukum Hak Asasi Manusia. Semarang. Badan Penerbit Universitas Diponegoro,.

Respationo, H. M. S. (2013). Pemilihan Kepala Daerah Demokrasi Electoral. Jurnal Magister Hukum, $42(3), 355-361$.

Syarbaini, S. (2002). Sosiologi dan Politik. Jakarta. Ghalia Indonesia.

Winarno. (2013). Paradigma Baru Pendidikan Kewarganegaraan. Jakarta. PT. Bumi Aksara.

Zazili, A. (2012). Pengakuan Negara Terhadap Hak-hak Politik Masyarakat Adat dalam Pelaksanaan PEemilihan Umum (Studi Putusan Mahkamah Konstitusi No.47-81/PHPU.A-VII/2009). Jurnal Konstitusi, 9(1), 108446. 